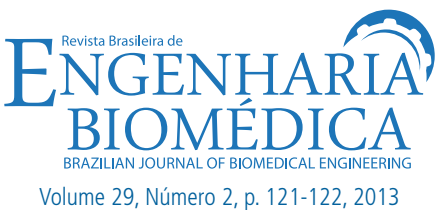

\title{
Inovar é preciso
}

\section{Alcimar Barbosa Soares, $\mathrm{PhD}$}

\author{
Editor-Chefe
}

Dentre os inúmeros desafios enfrentados pelos ditos "países em desenvolvimento", sem dúvida a distribuição justa da riqueza está entre os maiores. Aqui cabem, preliminarmente, dois esclarecimentos: (i) destaco o termo "países em desenvolvimento", pois, confesso, não sei se consigo compreender bem a métrica usada pelos organismos internacionais para defini-lo; (ii) o que aqui denomino "riqueza" deve, necessariamente, ir muito além de depósitos em contas bancárias ou posses dos cidadãos - como dizia um cartaz recentemente publicado em algumas redes sociais, "país rico não é país onde pobre tem carro; país rico é onde o rico anda de transporte público"... isso resumo um pouco do que gostaria de definir como riqueza de um país. Crescer e distribuir riqueza é um desafio imenso para qualquer nação. Distribuir riqueza é também dar oportunidades para que os cidadãos tenham acesso digno a um sistema educacional decente, é prover saneamento básico universal, é permitir que doentes possam ser cuidados com dignidade e permitir que tecnologias de ponta alcancem cada canto do país.

Aproximando a discussão de nosso métier, penso ser impossível falar em nação rica quando os corredores de seus hospitais estão amontoados de "leitos" com pacientes sofrendo enquanto transeuntes por eles passam, é impossível falar em riqueza quando a excelência no tratamento só é privilégio de alguns pouquíssimos endinheirados. Não defendo aqui a transição para qualquer regime político-social como solução, até porque essa discussão é terreno minado e não caberia em um editorial de uma revista científica da área de engenharia... ou talvez sim...

A maior parte dos "países em desenvolvimento" depende fortemente da exportação de seus recursos naturais e parecem entrar cada vez mais em uma possível espiral destrutiva: exporta-se commodities a alguns poucos dólares a tonelada e importa-se alta tecnologia (muitas vezes produzida com aquelas commodities) a milhões de dólares a tonelada. E assim, a conta não fecha. Certamente não há nada de errado em se importar alta tecnologia - nenhuma nação poderá produzir absolutamente tudo. O problema é a total dependência externa em setores estratégicos, como é o caso da saúde.

Vejamos o caso dos países latino americanos. Se observarmos seus Estabelecimentos de Assistência a Saúde (EAS), perceberemos que praticamente todos os equipamentos de ponta (e até mesmo alguns com baixa tecnologia embarcada) utilizados no dia-a-dia são importados. Sim, existem alguns poucos e importantes exemplos de uso de produtos nacionais... mas são a exceção, e não a regra. Como destaquei, não há mal algum em trabalharmos com equipamentos fabricados no exterior. Aliás, é até fundamental em muitos casos. Mas, se tal dependência atingir patamares importantes, como tem sido o caso nesta região do planeta, os custos podem ser altíssimos para as nações. E custo alto sempre implicará na menor disseminação daquelas tecnologias - o que, em última análise, significa que não chegarão a todos que necessitam.

Mas, não é só de "hardware" que vive um sistema de saúde. Há muito que se fazer para mudar o modus operandi vigente nos EAS, em que processos de gestão ultrapassados ainda são, teimosamente, repetidos. Milhões são gastos, por exemplo, em contratos desatualizados, em serviços ineficientes e na aquisição de equipamentos inadequados (muitas vezes até superdimensionados) para a realidade local.

Precisamos "inovar". Sim, inovar. E inovar significa, por exemplo, fazer chegar às pessoas novas tecnologias e novos processos de gestão dos hospitais de sua região. E, neste aspecto, nós Engenheiros Biomédicos podemos e devemos dar nossa contribuição. Muita pesquisa de qualidade é desenvolvida dia após dia em nossos laboratórios. Prova disso são os excelentes artigos publicados nesta Revista. Mas, precisamos ir agora um pouco além. Precisamos tirar nossas dissertações, teses e artigos da prateleira. De fato, existem 
muitos que já o fazem primorosamente - pesquisam, registram patentes e conseguem até mesmo transferir a tecnologia gerada para o setor industrial. Mas, repetindo o que disse antes, são a exceção. Também é verdade que muita pesquisa não é necessariamente "transferível". Afinal, pesquisa de base é absolutamente essencial e não deve ser preterida em favor da chamada pesquisa "aplicada". De qualquer forma, meu ponto é que podemos sim, gerar conhecimento e tecnologias nacionais que beneficiarão diretamente milhões de pessoas em nossas nações. É perfeitamente possível transformarmos nossas dissertações, teses e artigos no bem estar de nossos povos.

O desafio e o discurso não são novos e têm sido martelados constantemente em foros por todo o mundo. A palavra "inovação" está na moda. Até mesmo ministérios vinculados a governos federais mudaram recentemente sua denominação para incorporar esta importantíssima vertente mundial. Já podemos observar, brotando em diversos países, centros dedicados à inovação tecnológica em saúde, cujas metas alinham-se perfeitamente ao exposto neste texto. O futuro parece promissor.

Vencer o desafio de transformar nossa produção científica em inovação para a área de saúde é certamente um dos caminhos mais importantes para transformar nossas nações. E aqui, cada um de nós tem um importante papel a cumprir.

Bom trabalho a todos nós.

Nota do editor: Gostaria de lembrar a todos que a partir de 2014 a RBEB passará a publicar apenas trabalhos redigidos em inglês. Reforço aqui nosso cronograma de transição:

i. A partir da próxima edição (29(3) - setembro) e até o final do ano, a RBEB dará prioridade para publicação de artigos redigidos em inglês, sendo possível a publicação de artigos em português de excelência ou que tenham sido aprovados até julho;

ii. A partir de outubro de 2013, a RBEB só aceitará submissões de artigos redigidos em inglês; e

iii. A partir da primeira edição de 2014, a RBEB publicará apenas artigos redigidos em inglês. 